\title{
Monetary arrangements in a globalizing world: an introduction
}

\section{Matías Vernengo}

\section{INTRODUCTION}

This book is based on a conference held at Kalamazoo College Michigan. In 11-12 May 2001, on the lessons of the European Monetary Union (EMU) for the Americas. Much of the economic analysis of moving to EMU has been undertaken within the context of the Optimal Currency Area (OCA) paradigm, based on Mundell's (1961) seminal contribution. In that view money is viewed as having developed from a private sector cost minimization process to facilitate trading. Not surprisingly the main advantage of monetary integration in the OCA context is the reduction of transaction costs. ${ }^{1}$ Yet the validity of OCA to analyse processes of monetary integration seems to be limited at best (Goodhart, 1998).

The discussions in the conference, that are partly reflected in the chapters of the book, try to go beyond the OCA model and understand the political economy of monetary integration by comparing the EMU with the dollarization (formal and informal) process in Latin America. ${ }^{2}$ Although it is clear that no consensus was reached during the conference - something that was dubbed the Kalamazoo Dissensus by one participant - it was clear for all that monetary integration, from the more loose arrangements to the more tight including Currency Boards and formal dollarization, is no panacea.

The debate on monetary integration and dollarization is an extension of the debate on the appropriate exchange rate regime, but also is part of a broader discussion. The question is whether global financial integration would lead to fewer currencies and whether that is desirable. Cohen (2004) refers to the notion that the number of currencies around the world will shrink as the Contraction Contention, and he argues that that hypothesis is fundamentally incorrect.

Several authors have shown that territorial currencies controlled by national states are a relatively recent phenomena dating from the nineteenth Century. ${ }^{3}$ However, it is clear that the advantages of national currencies outweigh the costs of forgoing a certain degree of monetary sovereignty, making resistance to 
monetary integration in all its forms a very likely strategy for national governments around the world. In this view, referred to as the Chartal (or Cartalist) view of money creation, the power of issuing money is central to the analysis, and the political relationship between control over money and political sovereignty is the key to understanding the future organization of international monetary arrangements.

Helleiner (2003) suggests that beyond the reduction of transaction costs in the domestic market the push towards national currencies in the nineteenth Century - facilitated by technical innovations in the minting process and improved capabilities against counterfeiting that led to a veritable coinage revolution - was caused by at least three additional motives. First, countries opted for territorial currencies because they desired to control monetary policy for domestic purposes. ${ }^{4}$ Second, territorial currencies by providing seigniorage revenues increase the fiscal options of the state. Not surprisingly the typical complaint against monetary integration is related to the loss of seigniorage revenues (see Berg and Borensztein, 2000).

Helleiner (2003, p. 10) suggests that the fiscal advantages of monetary integration should not be reduced to the seigniorage gains, but more importantly to the reduction in the transaction costs associated with the management of complex fiscal bureaucracies. From a Chartal perspective, even more important would be the fact that the ability to enforce the currency in which taxes have to be paid allows governments to increase the acceptable levels of taxation. Not surprisingly Tanzi and Schuknecht (2000, pp. 52-3) show that the average level of government revenue for a list of developed countries was around 10 percent of GDP in 1870, at the time that national currencies had been recently established or were in the process of being established, while the same measure was close to 40 percent of GDP by the end of the twentieth Century. ${ }^{5}$

This suggests that the conventional OCA approach has downplayed the interaction between monetary and fiscal policy and consequently severely underestimated the costs of giving up monetary sovereignty. Not only national currencies seem to be associated with higher levels of taxation, but also high international transaction costs reducing foreign exchange transactions, historically allowed governments to maintain domestic interest rates at relatively low levels and finance public debt denominated in local currency at reduced cost. This was the basis for Keynes's position in favor of capital controls during the Bretton Woods negotiations (Vernengo and Rochon, 2000).

Furthermore, it appears that territorial currencies may be central for countries to pursue expansionary macroeconomic policies, but the ability to do so is restricted by the willingness of the hegemonic country to accept, and even promote as the USA did during the Bretton Woods period, a relatively closed international financial system. In that respect, the problems for peripheral countries are not only associated with the challenges to domestic currencies such as processes of 
monetary integration, but more broadly speaking their problems are related to the international financial regime. ${ }^{6}$

In other words, a country that maintains its national currency, but has a relatively open and deregulated capital account, allowing free movement of capital, will also retain its ability to pursue monetary and fiscal policy for domestic purposes. ${ }^{7}$ The last important reason countries hold to territorial currencies, according to Helleiner, is that domestic currencies strengthen the national identity. By increasing the sense of national sovereignty territorial currencies may foster active national macroeconomic management.

This is clearly one of the major differences between the EMU and the extension of currency boards and dollarization throughout the periphery. The European experiment shares monetary sovereignty with all the participating members and it allows for significant fiscal transfers from the richer countries in the union to those in need. Clearly those arrangements are less than perfect, and some chapters in this book will emphasize the limitations, but the macroeconomic implications of monetary integration in the periphery are undeniably harsher. Hence, one would expect a lot of resistance to the elimination of domestic currencies in emerging markets, something that maybe termed the Resistance Contention.

The Contraction Contention built on the OCA framework disregards the limitations imposed on national macroeconomic policies and the political importance that these policies might have. For that reason, even though it is very likely that domestic currencies will continue to be popular for a long while, the OCA framework misses the point. Some evidence in favor of the Resistance Contention is visible in the diminished enthusiasm for dollarization since the conference was held, and also from the increased respectability for what Rudiger Dornbusch referred to as the BBC rules, that is, Band, Basket and Crawl, which reflect intermediary exchange rate arrangements (Williamson, 2000, p.6).

The bipolar view, which claimed that developing countries in particular should either float their currencies or pursue a hard peg has been exaggerated as admitted by Stanley Fischer (2001, p. 5). Jeffrey Frankel (1999, p. 30) noted correctly that 'intermediate solutions are more likely to be appropriate for many countries than are corner solutions.' In addition, it has been noted that most countries that float their currencies actually intervene to avoid extreme fluctuations (Calvo and Reinhart, 2002). This suggests that capital controls understood as measures that limit exchange rate volatility by reducing the size of the foreign exchange market - cannot be completely taken off the agenda. ${ }^{8}$

The Resistance Contention raises a broader question regarding dollarization. Dollarization may be seen as a specific monetary arrangement by which a country adopts a foreign currency (the dollar in most cases, hence the name) formally or informally. However, it is clear that since the Bretton Woods agree- 
ment and more so after its demise in 1973 the world economy has been under a dollar standard regime. The role of the US dollar as key currency in international financial markets can be seen as a more wide-ranging form of dollarization.

As noted by D'Arista (2004, p. 558) 'the share of dollar assets in international reserve holdings, the high level of dollar-denominated debt owed both to foreign and domestic creditors by borrowers in countries other than the United States, the amount of US currency held and exchanged outside the United States by residents of other countries, and the impact of changes in US interest rates and the value of the dollar on developments in the global economy are all among the pervasive manifestations of dollar dominance.' As US trade deficits increased and its net international liabilities mounted, questions about the sustainability of the global system became more unrelenting. Notwithstanding the resilience of the dollar has been incredible. ${ }^{9}$

This is probably the great paradox of our times. On the one hand, dollarization in a broad sense has been widespread for the last half-century, leading to increasing imbalances in the balance of payments accounts of almost every country. This has been forcefully pushed by the USA, in particular those that benefit from the dollar's position in financial markets, what Bhagwati called the Treasury-Wall Street complex. On the other hand, resistance in the periphery makes it less likely that a reduction of the number of currencies - in extremis dollarization in a narrow sense - will eventually take place. The US dollar will most likely remain in the midway limbo, without substituting other national currencies, but maintaining a dominant position in financial markets. The limits to this monetary arrangement are always being tested, and the fears are that a financial tsunami will drive the dollar, and the world economy, to a major crisis.

\section{AN OUTLINE OF THE BOOK}

The contributions in this volume reflect the disagreements and the changing views on the proper monetary arrangements in a globalized world, and suggest that monetary integration and dollarization are not the solution for the great majority of countries around the world. The chapters in Part 1 deal with the European Monetary Union. In Chapter 1 Arestis and Sawyer briefly review the establishment in the European Union (EU) of the EMU and the single currency (euro) experiment as instituted in January 1999, and argue that the present arrangements governing the euro do not involve mechanisms for the reduction of the disparities of unemployment and GDP per head. They suggest that fiscal policy and a social security system operating at the level of the monetary union are required to promote a more equitable integration. 
In Chapter 2 Ponsot describes the Eastern European experience with currency boards and the possibilities open by the EMU. In particular, the strict limitations imposed by the currency board arrangement, and the difficulty of reverting to a central banking system, indicate for him that the only possible way out seems to be euroization.

Parguez provides a severe indictment of the EMU, both of its theoretical foundations and of its effective achievements so far, in Chapter 3. In particular, the criticism is associated to the poor foundations provided by the OCA approach, and the economic straitjacket that is imposed on European societies. Hence, for Parguez the lesson is clear: there is no reason to create a monetary union in the Americas.

The chapters in Part 2 shift the attention to the problems of foreign exchange choice in North America. Gruben and Koo discuss in Chapter 4 whether NAFTA has moved North America closer to an optimal currency area. They argue that some change in business cycle synchronicity has occurred between Mexico and the United States, and that a similar, but less pronounced change might have occurred in between Canada and Mexico at least in comparison with previous periods. According to the authors this suggests that a positive move towards currency union has occurred.

In Chapter 5 Pozo tries to analyse the possible effects of dollarization in Mexico on illegal immigration into the United States. The conclusions derived are based on the reliability of the adjusted apprehension data as an estimate of illegal immigration into the USA from Mexico, and the notion that dollarization will result in greater stability in relative prices between Mexico and the USA. Under those assumptions, Pozo's results suggest that dollarization leads to a reduction in the level of illegal immigration.

Chapters 6 and 7 are dedicated to the discussion of whether the Canadian dollar should survive or not. Seccareccia argues that there are clear political forces at work in Canada, moving in the direction of greater monetary integration with the United States, who have employed OCA theory to further their specific political ends. However, Seccareccia suggests that OCA theory rests on terribly shaky foundations, and that the benefits of moving in the direction of greater monetary integration are highly uncertain. Bodkin agrees in his spirited contribution that the present Canadian system of foreign exchange rate regimes is probably not ideal, but that the majority of his fellow Canadian citizens prefer it anyway, and that should count for something.

Part 3 shifts the emphasis to the question of the appropriate exchange rate regime for developing countries, also known as emerging markets, despite the fact that several have literally submerged in the last decade under the pressure of several waves (tsunamis?) of financial crisis. For that reason the need for reforming the international financial architecture is also discussed. Eichengreen suggests in Chapter 8 that the Asian crisis and its fallout in Latin America and 
Eastern Europe convinced many observers that soft currency pegs are crisis prone and that emerging markets should embrace greater exchange rate flexibility. In that case, inflation targeting provides a coherent alternative to exchange-rate-based monetary policy strategies that are overly restrictive and crisis prone.

In Chapter 9 Studart makes a case that the increase of financial flows between developed and developing economies is inherently destabilizing due to the wide differences between financial markets in mature and developing economies. For that reason he concludes that in the absence of substantive reforms of the international financial institutions, developing economies should be able to shelter from destabilizing effects of short-term volatile capital inflows.

Griffith-Jones argues in Chapter 10 that after several financial crises there is a broad consensus that fundamental reforms are required in the international financial system. Particularly problematic in her view is the lack of institutions that provide international liquidity, an international lender of last resort. Griffith-Jones points out that the International Monetary Fund (IMF) provides emergency financing but not liquidity, and, although the IMF has the capacity to create fiat money, through the issue of Special Drawing Rights (SDRs), those were used in the past only in a very limited way.

In Chapter 11 Medeiros and Serrano take a broader political economy view of the changes in the international economy. They argue that in the current floating dollar standard the balance of payments situation facing the emerging markets is characterized by a basic contradiction. On one hand, it is extremely easy to attract large amounts of foreign capital. On the other hand, it has become more and more difficult to deliver the fast growth of exports that is a necessary condition for the financial servicing of these inflows.

The last part of the book presents general reflections on the question of monetary integration and dollarization. Vernengo argues in Chapter 12 that dollarization - understood as the substitution of domestic currency for a foreign one - does not imply an automatic adjustment of the balance of payments. Further, the deflationary stance imposed on dollarizing countries is only a recent variation of a longer story. More importantly, the author argues that the collapse of Bretton Woods implies that dollarization is more rather than less widespread, and this has led to lower levels of growth, higher rates of interest, and has increased the degree of financial fragility of the world economy.

In Chapter 13 Davidson provides an interesting taxonomy for analysing dollarization processes. Davidson distinguishes between open and closed economies, on the one hand, and between unionized monetary systems and non-unionized monetary systems, on the other. Monetary integration and dollarization are forms of unionized monetary systems. If open economies decide to enter unionized monetary systems, then severe balance of payments can occur in the absence of a supra-national authority capable of providing fiscal transfers. 
In Chapter 14 Jameson discusses the reasons for the diminished prospects of formal dollarization in the Western Hemisphere. He notes that at the time of the conference in May 2001, it seemed possible that the entire Western Hemisphere would soon move toward adopting the dollar as the uniform currency, but now a Western Hemisphere Monetary Union no longer seems likely; the dollarization momentum has diminished. The move toward greater exchange rate flexibility has been the result, to a great extent, of renewed capital flows to Latin America.

In the last chapter Câmara Neto and Vernengo try to determine the main lessons from the conference. Monetary unions and dollarization are sometimes suggested as solutions to excessive inflation, excessive foreign exchange risk and high interest rates, low levels of economic growth, too much illegal immigration and a variety of economic problems. However, it was clear from the discussions in the conference that in the real world monetary integration and dollarization are no panacea. They may solve some problems, but usually at high costs.

In particular, it seems that even though monetary integration and dollarization can deliver low levels of inflation - or at least bring inflation down to international levels, which is not necessarily the same - the costs in terms of growth and employment are high. In cases where fiscal policy can mitigate the effects on unemployment the costs of monetary unions are smaller and more bearable. Hence, in Europe a reform of the Stability and Growth pact allowing less stringent limits on budget deficits and debt would strengthen rather than weaken the monetary union. The lack of any program of fiscal transfers makes dollarization in North America and in other emerging markets less likely. The cries for reform in Europe and the renewed interest in intermediate solutions for exchange rate policy in the developing world suggest that those conclusions have been vindicated by events since the conference took place. The time elapsed since the conference, hence, has not diminished the value of the contributions here presented.

My interest on dollarization and monetary integration started with the adoption of the currency board in Argentina, and the implementation of a system of fixed exchange rates in Brazil slightly later. Lance Taylor suggested my name to the organizers of a conference at the Banco Central de Ecuador in 2000 that allowed me to meet moderate critics of the idea, such as Benjamin Cohen and Joseph Stiglitz and strong supporters like Eduardo Borensztein from the International Monetary Fund. I would like to thank Marco Baquero, Diego Mancheno and Pedro Paez for important discussions about the Ecuadorian experience.

Several participants enriched the discussions but their final contributions did not make it into the book. Robert Barro, Per Gunnar Berglund, Alfredo Calcagno, Jane D’Arista, José Maria Fanelli, Ricardo Hausmann, Jomo K.S., Marc 
Lavoie and Carol Wise provided insights that are not completely lost in the remaining revised contributions. I thank them all for that.

A grant from the Ford Foundation made the conference possible. I would like to thank Manuel Montes for his incredible patience during the long gestation of the book. Marilyn Cake and several students at Kalamazoo College made the two-day conference possible and enjoyable. James Jones, the then president of the College, and above all Hannah McKinney, the department chair, supported the project in all possible ways. More importantly they showed, at a difficult point, that honesty and integrity are always rewarded. Chuck Stull, and his family, Suzan, Ricardo and Maria were incredible friends in the good and bad times of our Kalamazoo stay. Yongbok Jeon and Carlos Schonerwald da Silva, and the editorial staff at Edward Elgar were instrumental in preparing the final version of the book. Finally, Marcia and Piero provided the necessary dose of love to make it all worthwhile.

\section{NOTES}

1. There is a catalogue of conditions that determine whether an area is an OCA or not. Two important issues are whether the whole area is affected by symmetric economic shocks, leading to the need of similar macroeconomic policies, and whether wage or labor flexibility can take the brunt of a regional balance of payments adjustment in the absence of exchange rate devaluations. De Grauwe (1997) provides a comprehensive and accessible introduction to the topic.

2. In that respect the focus is slightly different from the one pursued in Salvatore et al. (2003) and Levy Yeyati and Sturzenegger (2003).

3. See Helleiner (2003), Rochon and Vernengo (2003) and Cohen (2004).

4. Helleiner (2003) supposes that monetary policy has concentrated on the control of the money supply, fundamentally as a result of the need to follow the rules of the game of the gold standard. This reflects an incorrect perception of the functioning of that system. Current understanding of that system suggests that the control of the rate of interest and not monetary aggregates was at the center of policy decisions (Bordo and Kydland, 1996). For a critical perspective on the functioning of the gold standard see Vernengo (2003).

5. The list of countries includes Australia, France, Italy, Ireland, Japan, New Zealand, Norway, the United Kingdom and the United States.

6. Monetary integration refers to the use, in different degrees, of an external currency as a substitute for the national one. Financial integration corresponds to the degree of capital mobility. Countries may very well stay clear of monetary integration arrangements and still choose to integrate into financial markets by eliminating all types of capital controls.

7. The incompatibility between capital mobility, national autonomy in the conduct of monetary policy, and fixed exchange rate systems is well known in the literature. Here it is suggested that even with flexible exchange rates, capital mobility is incompatible with national autonomy in the conduct of both monetary and fiscal policies.

8. The literature on capital controls has surged lately. Wade (1998-9) and Dunn (2002) provide opposing views. For a defense of capital controls see also Vernengo and Rochon (2000).

9. Frank (2003, p. 252) suggests the resilience of the dollar is connected to American power to coerce other governments to hold dollar denominated assets, which ultimately is related to American military power. 


\section{REFERENCES}

Berg, A. and E. Borensztein (2000), 'The pros and cons of full dollarization,' IMF working paper No 00/50, Washington, DC.

Bordo, M. and F. Kydland (1996), 'The Gold Standard as a commitment mechanism,' in T. Bayoumi, B. Eichengreen and M. Taylor (eds), Modern Perspectives on the Gold Standard, Cambridge, UK: Cambridge University Press.

Calvo, G. and C. Reinhart (2002), 'Fear of floating,' Quarterly Journal of Economics, 117 (2), 379-408.

Cohen, B. (2004), The Future of Money, Princeton, NJ: Princeton University Press.

D'Arista, J. (2004), 'Dollars, debt, and dependence: the case for international monetary reform,' Journal of Post Keynesian Economics, 26 (4), Summer, 557-72.

De Grauwe, P. (1997), The Economics of Monetary Integration, New York: Oxford University Press, 3rd edition.

Dunn, Jr., R. (2002), 'The misguided attractions of foreign exchange controls,' Challenge, September-October, 98-111.

Fischer, S. (2001), 'Exchange rate regimes: is the bipolar view correct?' Journal of Economic Perspectives, 15 (2), Spring, 3-24.

Frank, E. (2003), 'The surprising resilience of the US dollar,' Review of Radical Political Economy, 35 (3).

Frankel, J. (1999), 'No single currency regime is right for all countries or at all times,' Princeton Essays in International Finance, no. 215 (August).

Goodhart, C. (1998), 'The two concepts of money: implications for the analysis of optimal currency areas,' European Journal of Political Economy, 14 (3), 407-32.

Helleiner, E. (2003), The Making of National Money: Territorial Currencies in Historical Perspective, Ithaca: Cornell University Press.

Levy Yeyati, E. and F. Sturzenegger (eds) (2003), Dollarization: Debates and Policy Alternatives, Cambridge: MIT Press.

Mundell, R.A. (1961), 'A theory of optimal currency areas,' American Economic Review, 53 (1), 657-64.

Rochon, L-P. and M. Vernengo (2003), 'State money and the real world: Chartalism and its discontents,' Journal of Post Keynesian Economics, 26 (1), Fall, 57-67.

Salvatore, D., J. Dean and T. Willett (2003), (eds), The Dollarization Debate, New York: Oxford University Press.

Tanzi, V. and L. Schuknecht (2000), Public Spending in the 20th Century, Cambridge, UK: Cambridge University Press.

Vernengo, M. (2003), 'The Gold Standard and centre-periphery interactions,' in L-P. Rochon and S. Rossi (eds), Modern Theories of Money: the Nature and Role of Money in Capitalist Economies, Cheltenham, UK and Northampton, MA, USA: Edward Elgar.

Vernengo, M. and L-P. Rochon (2000), 'Exchange Rate Regimes and Capital Controls,' Challenge, 43 (6), November-December, 76-92.

Wade, R. (1998-9), 'The coming fight over capital controls,' Foreign Policy, Winter, 41-54.

Williamson, J. (2000), Exchange Rate Regimes for Emerging Markets: Reviving the Intermediate Option, Washington, DC: Institute for International Economics. 
Matías Vernengo - 9781847200259 Downloaded from PubFactory at 04/26/2023 03:23:19PM via free access 